\title{
JUSTICIABELEN
}

Jurnal Hukum

Journal homepage: http://journal.umg.ac.id/index.php/justiciabelen/index

\section{Kewenangan Dewan Perwakilan Daerah Dalam Pengawasan Peraturan Daerah}

Muhammad Roqib, S.H., M.H

Universitas Muhammadiyah Gresik, Jl. Sumatera No.101, Gn. Malang, Randuagung, Kec.

Kebomas, Kabupaten Gresik, Jawa Timur 61121, Indonesia.

Muhammadroqib.umg@gmail.com

\begin{tabular}{l} 
Kata Kunci : \\
\hline Regional Representative \\
Council, authority, monitoring \\
of regency/city regional \\
regulation(s), testing and \\
nullifying of regional \\
regulation(s).
\end{tabular}

ABSTRAK

Regional Representative Council (Dewan Perwakilan Daerah/DPD) is a constitution organ. This one of state institutions is established and empowered by the 1945 Constitution. The existence of the Regional Representative Council is regulated in the provision of Chapter VII Article $22 \mathrm{C}$ and Article $22 \mathrm{D}$ of the 1945 Constitution. The authorities and duties of the Regional Representative Council is regulated in No. 2/2018 of Law about the People's Consultative Assembly (MPR), the House of Representative (DPR), the Regional Representative Council (DPD), and the Regional People's Representative Council (DPRD). One of the Regional Representative Council's authorities in the Law No. $2 / 2018$ is able to monitor and evaluate the regional regulations plan and the regional regulations. However, since the verdict of Constitutional Court No. 137/PUU XIII/2015 and 56/PUU-XIV/2016 about revocation of the government authority (central) to nullify (executive review) the regional regulation, the authority of the Regional Representative Council in monitoring the regional regulations plan and the regional regulations is weakened and not clear. The nullification of the regional regulation(s) is owned by judicial institution only, such as the Supreme Court (MA). In fact, the Regional Representative Council should be as a representative council that can associate those two interests at once, the central government in top down way and regional interest in bottom up way. How does the Regional Representative Council align those two waves of interests at once through the regional regulation(s)? This research uses statute approach, by examining the related laws about law issues which is already analyzed and also uses conceptual approach, which starts from the point of views and developed doctrines in the legal studies. Based on the research results, it was known that the verdict of the Constitutional Court did not eliminate the control of the central government, in this case was the Regional Representative Council to the regional government, including the making of the regency/city regional regulations. But, this control was not in the shape of testing or nullifying the regional regulations. The Regional Representative Council in consort with the ministry, and governor as the representative of the central government should do some evaluation process on each regional regulations plan. 


\section{Pendahuluan}

Dewan Perwakilan Daerah (DPD), merupakan lembaga negara baru berdasarkan amandemen ketiga UndangUndang Dasar Negara Republik Indonesia Tahun 1945, tepatnya diatur dalam ketentuan Bab VII A Pasal 22 C dan Pasal 22 D. Lembaga ini merupakan pengganti utusan-utusan daerah dan utusan-utusan golongan yang dikenal sebelumnya, di mana keduanya merupakan unsur keanggotaan Majelis Permusyawaratan Rakyat.

DPD dilahirkan dan ditampilkan sebagai salah satu lembaga perwakilan rakyat yang akan menjembatani kebijakan (policy), dan regulasi pada skala nasional oleh pemerintah pusat di satu sisi dan daerah di sisi lain. Terjadi semacam perubahan strategi dari pola representasi kepentingan daerah melalui penempatan utusan daerah di MPR kepada pola representasi melalui dewan yang khusus ditugasi konstitusi untuk memperjuangkan kepentingan daerah.

Meskipun DPD itu akan bertugas di pusat pemerintahan, namun DPD tidak terlepas dari konteks dan situasi serta kondisi daerah, termasuk kerangka hukum konstitusi (constitutional frame) yang menjadi paradigma yuridis-konstitusional bagi penyelenggara pemerintah di daerah.

Menurut kajian ketatanegaraan, khususnya mengenai pemerintah dan otonomi daerah sering disebut bahwa di daerah itu akan berlangsung sekaligus dua arus kebijakan, yakni berlangsungnya kekuasaan dan kewibawaan pusat di daerah dari satu arah secara top down dan sekaligus berlangsung pendemokrasian pemerintahan dan akomodasi aspirasi masyarakat daerah dari arah lain, secara bottom up, maka dapat dikatakan bahwa konstitusi mengamanatkan kepada DPD untuk

\footnotetext{
${ }^{1}$ M. Solly Lubis, Hukum Tata Negara (CV. Mandar Maju 2008).[94].
}

menjembatani kedua kepentingan kebijakan ini. $^{1}$

Di samping itu, DPD juga harus merujuk kepada Pasal 18 A dan Pasal 18 B UUD NRI Tahun 1945 yang mengintroduksi untuk berfungsinya paradigma filosofis kultural yakni patokan agar penerapan hubungan antara pemerintahan (pusat) dan daerah dilaksanakan dengan memperhatikan khususnya dan keragaman daerah serta menjaga tradisi yang masih eksis di daerah.

Keanggotaan DPD berdasarkan ketentuan Pasal $22 \mathrm{C}$ ayat (1) UUD NRI Tahun 1945 terdiri atas wakil-wakil daerah provinsi yang dipilih melalui pemilihan umum, hal ini berbeda dengan utusan daerah dan utusan golongan yang pada saat itu pengisian keanggotaannya diangkat.

Keanggotaan DPD dari setiap provinsi jumlahnya sama untuk masing-masing provinsi yaitu 4 orang atau kursi dan tidak mempertimbangkan luas daerah dan penduduknya, artinya penentuan jumlah anggota DPD ditentukan berdasarkan administrasi kewilayahan. Hal ini berbeda dengan penentuan alokasi kursi untuk DPR RI dari masing-masing daerah pemilihan yang mempertimbangkan luas wilayah dan kepadatan penduduknya. Di Amerika Serikat, keberadaan DPD ini mirip dengan senator yang merupakan wakil-wakil dari negara bagian, dan jumlah senator yaitu 4 orang untuk masing-masing negara bagian. Kemudian, jumlah seluruh anggota DPD tersebut tidak lebih dari sepertiga dari jumlah anggota Dewan Perwakilan Rakyat.

Apabila dilihat dari kewenangan yang dimiliki oleh DPD dan dibandingkan dengan kewenangan yang dimiliki oleh DPR, maka kewenangan DPD tersebut sangat kecil dan lemah. Secara teoritis, konstruksi parlemen dua kamar (bicameral) memang bervariasi, dari yang kuat (strong bicameralism) seperti di Amerika Serikat hingga yang lunak atau lemah (soft bicameralism) seperti di Austria. Oleh

\footnotetext{
${ }^{2}$ Nuruddin Hady, Teori Konstitusi \& Negara Demokrasi (Setara Press 2016).[123].
} 
karena itu, lemahnya kewenangan yang dimiliki oleh DPD tersebut memunculkan banyak kritikan bahwa DPD tidak lebih dari staf ahli yang subordinat terhadap DPR, sehingga memunculkan gagasan perlunya amandemen kembali terhadap UUD NRI Tahun 1945, khususnya terkait dengan kewenangan untuk memperkuat kewenangan DPD. ${ }^{3}$

Dari ketentuan dalam UUD NRI Tahun 1945 ataupun Undang-Undang Republik Indonesia Nomor 7 Tahun 2017 tentang Pemilihan Umum dan Undang-Undang Republik Indonesia Nomor 2 Tahun 2018 tentang Perubahan Kedua Atas UndangUndang Republik Indonesia Nomor 17 Tahun 2014 tentang Majelis Permusyawaratan Rakyat, Dewan Perwakilan Rakyat, Dewan Perwakilan Daerah, dan Dewan Perwakilan Rakyat Daerah, maka mekanisme pengisian jabatan keanggotaan DPD tampak lebih berat bila dibandingkan dengan mekanisme pengisian anggota DPR. Peserta pemilu menjadi anggota DPD adalah perorangan, sedangkan peserta pemilu untuk anggota DPR adalah partai politik. Artinya, dapat terjadi tokoh perorangan yang akan tampil sebagai calon anggota DPD menghadapi kesulitan luar biasa dalam menggalang dukungan dirinya, sedangkan calon anggota DPR cukup memanfaatkan (mendompleng) struktur partai politiknya sebagai mesin menghimpun dukungan suara dalam pemilihan umum. Meskipun demikian, eksistensi anggota DPD dipandang lebih memiliki legitimasi sosial yang amat kuat karena dipilih langsung oleh masyarakat lokal, sedangkan rekrutmen anggota DPR/DPRD masih terbuka peluang untuk berperan kuatnya para pimpinan partai politik dalam menentukan siapa yang akan ditempatkan menjadi anggota DPR/DPRD.

Secara umum, basis komunitas dari setiap calon anggota DPD setidaknya berasal dari empat unsur utama. Pertama,

\footnotetext{
${ }^{3}$ Ibid.

${ }^{4}$ Ni'Matul Huda, Hukum Tata Negara Indonesia (PT Rajagrafindo Persada 2005).[179].

basis komunitas spatial (space base community) dengan kemungkinan bersumber dari etnik atau daerah pemilihan kabupaten/kota tertentu (yang tidak ditentukan semangat etnik, tetapi lebih pada semangat asal daerah). Kedua, basis komunitas dari suatu organisasi tertentu yang memiliki basis dukungan massa yang kuat di tingkat lokal (provinsi/kabupaten/kota), misalnya dari unsur Nahdlatul Ulama (NU), Muhammadiyah, unsur pimpinan agama tertentu yang membasis di tingkat lokal, dan semacamnya. Ketiga, dari figur publik yang dikenal atau akan dipilih karena kepopulerannya, baik dari kalangan kampus maupun aktivis kondang, LSM, dan sebagainya. Keempat, elite ekonomi, yakni mereka yang memiliki kekuatan materi sehingga dikenal masyarakat dan apalagi bila dalam proses-proses kampanye. Persaingan dari figur keempat unsur ini, akan mewarnai proses-proses kampanye dan pemilihan anggota DPD dalam pemilu 2019. ${ }^{4}$

Eksistensi DPD berupa posisi tawar, kapasitas, dan citra kelembagaannya jelas akan dipengaruhi latar belakang figur-figur yang mengisinya. Untuk itu, diharapkan yang akan tampil mengisi keanggotaan DPD adalah figur-figur yang kritis, independen dan memiliki kapasitas individu sebagai anggota DPD, yang mampu mengekspresikan aspirasi masyarakat daerah secara langsung dalam proses-proses pengambilan kebijakan di tingkat nasional dan jangan sampai DPD hanya menjadi tempat 'mangkal pemain-pemain lama'. Kalau hal itu yang terjadi, apa beda DPD dengan DPA di masa lalu. Ketika itu, DPA telah berubah menjadi Dewan Pensiunan Agung, apa akan mengulang hal yang sama pada DPD menjadi Dewan Pensiunan Daerah. $^{5}$

Dalam Undang-Undang Republik Indonesia Nomor 2 Tahun 2018 tentang

${ }^{5}$ Ibid. [180]. 
Perubahan Kedua Atas Undang-Undang Republik Indonesia Nomor 17 Tahun 2014 tentang Majelis Permusyawaratan Rakyat, Dewan Perwakilan Rakyat, Dewan Perwakilan Daerah, dan Dewan Perwakilan Rakyat Daerah, dinyatakan tentang wewenang dan tugas DPD pada Pasal 249 dan Pasal 250. Dalam Pasal 249 ayat (1) huruf $\mathrm{j}$ disebutkan "DPD mempunyai wewenang dan tugas :".

"Melakukan pemantauan dan evaluasi atas rancangan peraturan daerah dan peraturan daerah."

Namun, wewenang dan tugas DPD dalam hal melakukan pemantauan dan evaluasi rancangan peraturan daerah dan peraturan daerah itu menjadi sangat lemah dan tidak memiliki kepastian hukum setelah terbitnya putusan Mahkamah Konstitusi Nomor 137/PUU-XIII/2015 dan 56/PUUXIV/2016 tentang pencabutan kewenangan pemerintah (pusat) untuk membatalkan (executive review) peraturan daerah. Sebelumnya, berdasarkan Undang-Undang Republik Indonesia Nomor 23 Tahun 2014 tentang Pemerintahan Daerah, wewenang executive review dimiliki oleh gubernur dalam membatalkan peraturan daerah kabupaten/kota dan Kementerian Dalam Negeri (Kemendagri) mempunyai wewenang membatalkan peraturan daerah provinsi.

Kewenangan tersebut pada dasarnya sudah dimiliki pemerintah sejak era orde baru melalui Undang-Undang Republik Indonesia Nomor 5 Tahun 1974 tentang Pokok-Pokok Pemerintahan Daerah hingga era reformasi saat ini melalui UndangUndang Nomor 22 Tahun 1999, UndangUndang Nomor 32 Tahun 2004, UndangUndang Nomor 23 Tahun 2014 tentang Pemerintahan Daerah. Namun, setelah sekian lama pemerintah mengemban wewenang tersebut, kini pembatalan peraturan daerah hanya dimiliki lembaga

\footnotetext{
${ }^{6}$ Yudha Prawira, 'Pasca Pencabutan Wewenang Executive Review atas Perda' (2017) www.hukumonline.com accesed 02 Desember 2018.
}

judicial semata yakni Mahkamah Agung (MA). ${ }^{6}$

Dari latar belakang tersebut di atas, timbul rumusan masalah yakni : (1) bagaimana kewenangan DPD menurut Undang-Undang Republik Indonesia Nomor 2 Tahun 2018 tentang Majelis Permusyawaratan Rakyat, Dewan Perwakilan Rakyat, Dewan Perwakilan Daerah, dan Dewan Perwakilan Rakyat Daerah, terkait pengawasan terhadap peraturan daerah pasca terbitnya putusan MK Nomor 137/PUU-XIII/2015 dan 56/PUU-XIV/2016 ?. (2) bagaimana fungsi DPD dalam menjembatani kepentingan pusat dan daerah melalui peraturan daerah $?$.

\section{Hasil dan Pembahasan}

Dalam sistem demokrasi modern dewasa ini, sistem kekuasaan dalam kehidupan bersama biasa dibedakan dalam tiga wilayah atau domain, yaitu negara (state), pasar (market), dan masyarakat (civil society). Ketiganya diidealkan harus berjalan seiring dan sejalan, sama-sama kuat dan sama-sama saling mengendalikan, tetapi tidak boleh saling mencampuri atau dicampuradukkan. Ketiga sistem kekuasaan tersebut jika dilihat dari sudut pembagian antara suprastruktur politik dan infrastruktur politik, maka negara (state) adalah wilayah suprastruktur politik. Adapun pasar (market) dan masyarakat (civil society) adalah wilayah infrastruktur politik. ${ }^{7}$

Sistem politik Indonesia yang harus dijalankan sesuai dengan Undang-Undang Dasar Negara Republik Indonesia Tahun 1945 adalah sistem politik berdasarkan hukum. Hal ini sesuai dengan dengan ketentuan Pasal 1 ayat (2) dan ayat (3) UUD NRI Tahun 1945 yang menyatakan bahwa kedaulatan berada di tangan rakyak dan dilaksanakan menurut UUD dan negara

\footnotetext{
${ }^{7}$ Jimly Asshiddiqie, Hukum Tata Negara \& PilarPilar Demokrasi (Sinar Grafika 2011).[268].
} 
Indonesia adalah negara hukum. Dengan demikian, tatanan dan kelembagaan politik, baik pada wilayah suprastruktur maupun infrastruktur harus dijalankan berdasarkan aturan hukum yang demokratis. ${ }^{8}$

Untuk memahami pengertian lembaga atau organ negara, seperti halnya lembaga Dewan Perwakilan Daerah, secara lebih dalam kita dapat mendekatinya dari pandangan Hans Kelsen mengenai the concept of the state organ dalam bukunya General Theory of Law and State. Hans Kelsen menguraikan bahwa Whoever fulfills a function determined by the legal order is an organ. Siapa saja yang menjalankan suatu fungsi yang ditentukan oleh suatu tata hukum (legal order) adalah suatu organ.

Artinya, organ negara itu tidak selalu berbentuk organik. Di samping organ yang berbentuk organik, lebih luas lagi, setiap jabatan yang ditentukan oleh hukum dapat pula disebut organ, asalkan fungsifungsinya itu bersifat menciptakan norma (normereating) dan/atau bersifat menjalankan norma (norm applying). These functions, by they of a norm creating or of a norm applying character, are all ultimately aimed at the execution of a legal sanction.

Menurut Kelsen, parlemen yang menetapkan undang-undang dan warga negara yang memilih para wakilnya melalui pemilihan umum sama-sama merupakan organ negara dalam arti luas. Demikian pula hakim yang mengadili dan menghukum penjahat dan terpidana yang menjalankan hukuman tersebut di lembaga pemasyarakatan, adalah juga merupakan organ negara. Pendek kata, dalam pengertian yang luas ini, organ negara identik dengan individu yang menjalankan fungsi atau jabatan tertentu dalam konteks

\footnotetext{
8 Ibid, [269].

${ }^{9}$ Pejabat yang biasa dikenal sebagai pejabat umum misalnya adalah notaris dan pejabat pembuat akta tanah (PPAT). Seringkali orang beranggapan seakan-akan hanya notaris dan PPAT yang merupakan pejabat umum. Padahal, semua 15
}

kegiatan bernegara. Inilah yang disebut jabatan publik atau jabatan umum (public officer) dan pejabat publik atau pejabat umum (public officials). ${ }^{9}$

Dikatakan oleh Hans Kelsen, An organ, in this sense, is an individual fulfilling as specific function. Kualitas individu itu sebagai organ negara ditentukan oleh fungsinya. He is an organ because and is so far as he performs a law creating or law applying function. Individu tersebut dapat disebut sebagai organ negara, karena ia menjalankan fungsi yang menciptakan hukum (law creating function) atau fungsi yang menerapkan hukum (law applying function).

Di samping pengertian luas itu, Hans Kelsen juga menguraikan adanya pengertian organ negara dalam arti yang sempit, yaitu pengertian organ dalam arti materiil. Individu dikatakan organ negara hanya apabila ia secara pribadi memiliki kedudukan yang tertentu (...he personally has a specific legal position). Suatu transaksi hukum perdata, misalnya, kontrak, adalah merupakan tindakan atau perbuatan yang menciptakan hukum seperti halnya suatu putusan pengadilan.

Lembaga negara terkadang disebut dengan istilah lembaga pemerintahan, lembaga pemerintahan nondepartemen, atau lembaga negara saja. Ada yang dibentuk berdasarkan atau karena diberi kekuasaan oleh UUD, ada pula yang dibentuk dan mendapatkan kekuasaannya dari undang-undang, dan bahkan ada pula yang hanya dibentuk berdasarkan Keputusan Presiden. Hierarki atau ranking kedudukannya tentu saja tergantung pada derajat pengaturannya menurut peraturan perundang-undangan yang berlaku. ${ }^{10}$

\footnotetext{
pejabat publik adalah pejabat umum. Karena yang dimaksud dalam kata jabatan umum itu tidak lain adalah jabatan public (public office), bukan dalam arti general office.

${ }^{10}$ Ibid, [270].
} 
Lembaga negara yang diatur dan dibentuk oleh UUD merupakan organ konstitusi, sedangkan yang dibentuk berdasarkan undang-undang merupakan organ undang-undang, sementara yang hanya dibentuk karena keputusan presiden tentunya lebih rendah lagi tingkatan dan derajat perlakuan hukum terhadap pejabat yang duduk di dalamnya. Demikian pula jika lembaga yang dimaksud dibentuk dan diberi kekuasaan berdasarkan Peraturan Daerah, tentu lebih rendah lagi tingkatannya.

Dalam setiap pembicaraan mengenai organisasi negara, ada dua unsur pokok yang saling berkaitan, yaitu organ dan functie. Organ adalah bentuk atau wadahnya, sedangkan functie adalah isinya; organ adalah status bentuknya (Inggris : form, Jerman : vorm), sedangkan functie adalah gerakan wadah itu sesuai maksud pembentukannya. Dalam naskah UndangUndang Dasar Negara Republik Indonesia Tahun 1945, organ-organ yang dimaksud, ada yang disebut secara eksplisit namanya, dan ada pula yang disebutkan eksplisit hanya fungsinya. Ada pula lembaga atau organ yang disebut bahwa baik namanya maupun fungsi atau kewenangannya akan diatur dengan peraturan yang lebih rendah.

Dewan Perwakilan Daerah jika dikaitkan dengan pandangan di atas maka merupakan organ konstitusi dan disebut secara eksplisit keberadaannya dalam Bab VII A UUD NRI Tahun 1945 yang terdiri atas Pasal 22 C dan Pasal 22 D. Dalam Pasal 22 D ayat (3) disebutkan"Dewan Perwakilan Daerah dapat melakukan pengawasan atas pelaksanaan undang-undang mengenai : otonomi daerah, pembentukan, pemekaran dan penggabungan daerah, hubungan pusat dan daerah, pengelolaan sumber daya alam dan sumber daya ekonomi lainnya, pelaksanaan anggaran pendapatan dan belanja negara, pajak, pendidikan, dan agama serta menyampaikan hasil pengawasan itu kepada Dewan Perwakilan

\footnotetext{
${ }^{11}$ Herdiansyah Hamzah, 'Pembatalan

Perda Pasca Putusan MK' (2017)
}

Rakyat sebagai bahan pertimbangan untuk ditindaklanjuti.".

Berdasarkan kewenangan yang diberikan oleh UUD itu, DPD dapat melakukan pengawasan atas pelaksanaan undang-undang mengenai otonomi daerah, hubungan pusat dan daerah. Kemudian, dalam Undang-Undang Republik Indonesia Nomor 2 Tahun 2018 tentang MPR, DPR, DPD, dan DPRD, Pasal 249 ayat (1) huruf j diatur wewenang dan tugas DPD yang menyebutkan "DPD mempunyai wewenang dan tugas : melakukan pemantauan dan evaluasi atas rancangan peraturan daerah dan peraturan daerah."

Namun, wewenang dan tugas DPD dalam hal melakukan pemantauan dan evaluasi rancangan peraturan daerah dan peraturan daerah itu menjadi sangat lemah dan tidak memiliki kepastian hukum setelah terbitnya putusan Mahkamah Konstitusi Nomor 137/PUU-XIII/2015 dan 56/PUUXIV/2016 tentang pencabutan kewenangan pemerintah (pusat) untuk membatalkan (executive review) peraturan daerah. Kini pembatalan peraturan daerah hanya dimiliki lembaga judicial semata yakni Mahkamah Agung (MA).

Dalam Undang-Undang Nomor 23 Tahun 2014 tentang Pemerintah Daerah diatur kewenangan pengawasan terhadap peraturan daerah secara vertikal berjenjang. Di mana kewenangan pengawasan terhadap peraturan daerah provinsi dilakukan oleh menteri, sedangkan pengawasan peraturan daerah kabupaten/kota dilakukan oleh gubernur sebagai wakil pemerintah pusat di daerah. Namun, dalam hal bentuk dan jenis pengawasannya, UU Pemda tersebut mengatur dua desain pengawasan terhadap peraturan daerah kabupaten/kota. ${ }^{11}$

Pertama, pengawasan preventif. Pemerintah pusat melalui gubernur diberikan kewenangan untuk melakukan proses evaluasi terhadap rancangan peraturan daerah kabupaten/kota, sebelum

www.tribunkaltim.co accessed 02 Desember 2018. 
ditetapkan oleh bupati/wali kota. Tetapi model pengawasan ini bersifat terbatas (limitatif). Hanya ditujukan untuk evaluasi rancangan perda mengenai RPJPD, RPJMD, APBD, perubahan APBD, pertanggungjawaban pelaksanaan APBD, pajak daerah, retribusi daerah, dan tata ruang daerah. Hal ini diatur dalam Pasal 245 ayat (3) UU Pemda.

Kedua, pengawasan represif. Dalam konsep ini, pemerintah pusat melalui menteri dan gubernur diberikan kewenangan untuk membatalkan peraturan daerah kabupaten/kota. Dalam Pasal 251 ayat (2) UU Pemda tersebut disebutkan, gubernur dapat membatalkan perda dengan alasan bertentangan dengan ketentuan peraturan perundangan yang lebih tinggi, kepentingan umum, dan/atau kesusilaan. Jika gubernur tidak membatalkan perda yang bertentangan tersebut, maka menteri dapat membatalkan perda, sebagaimana ketentuan Pasal 251 ayat (3) UU Pemda. Namun, sejak terbitnya keputusan MK tersebut, kewenangan gubernur dan menteri membatalkan peraturan daerah dicabut.

Dalam Undang-Undang Nomor 12 Tahun 2011 tentang Pembentukan Peraturan Perundang-undangan disebutkan bahwa perda merupakan salah satu bentuk peraturan perundang-undangan yang secara hierarkhi kedudukannya berada di bawah undang-undang. Oleh karena itu, berdasarkan ketentuan Pasal 24A ayat (1) Undang-Undang Dasar Negara Republik Indonesia Tahun 1945, yang kemudian dikuatkan dengan Pasal 9 ayat (2) UndangUndang Republik Indonesia Nomor 12 Tahun 2011, maka pengujian perda dilakukan oleh Mahkamah Agung.

Akan tetapi harus dipahami bahwa Indonesia adalah negara kesatuan, sebagaimana bunyi Pasal 1 ayat (1) UUD NRI Tahun 1945. Dalam prinsip negara kesatuan, hanya berlaku satu sistem hukum bagi pemerintah, baik di pusat maupun di daerah. Oleh karena itu, seberapa pun luas dan besarnya otonomi yang diberikan kepada daerah, tetap harus tunduk berdasarkan prinsip negara kesatuan, di mana kedaulatan hanya ada di pemerintah pusat. Dalam arti, kendali penyelenggaraan pemerintahan daerah berada di tangan pemerintah pusat, termasuk kontrol terhadap perda.

Putusan MK bersifat final dan mengikat. Artinya pemberlakuan mengikat dimulai pada saat dibacakan. Dalam konteks ini, MK telah memutus rantai perdebatan terkait pengujian perda kabupaten/kota. Putusan MK secara tegas memberikan kewenangan penuh kepada MA sebagai lembaga peradilan yang berhak menguji dan membatalkan perda kabupaten/koya (judicial review). Dengan demikian, pengawasan yang bersifat represif menjadi wewenang MA, sedangkan pengawasan yang bersifat preventif, menjadi tugas pemerintah pusat, termasuk dalam hal ini adalah tugas Dewan Perwakilan Daerah, bersama menteri dan gubernur. DPD yang merupakan representasi pemerintah pusat bersama menteri dan gubernur dapat melakukan pengawasan preventif terhadap rancangan peraturan daerah.

\section{Kesimpulan}

Mahkamah Konstitusi telah mengeluarkan putusan Nomor 137/PUUXIII/2015 dan 56/PUU-XIV/2016 yang isinya mencabut kewenangan pemerintah pusat untuk membatalkan (executive review) peraturan daerah.

Putusan MK ini tentu saja tidak menghilangkan kendali pemerintah pusat, dalam hal ini Dewan Perwakilan Daerah, terhadap pemerintahan daerah, termasuk dalam hal pembuatan perda kabupaten/kota. Namun, kendali tersebut tidak lagi dalam bentuk pengujian dan pembatalan perda (executive review). Dewan Perwakilan Daerah bersama menteri dan gubernur sebagai wakil pemerintah pusat, sebaiknya melakukan proses evaluasi terhadap setiap rancangan perda yang diusulkan. Di sisi 
lain, DPD juga dapat menyuarakan dan mengusulkan aspirasi dan kepentingan daerah kepada pemerintah pusat melalui rancangan peraturan daerah.

Dengan demikian, rancangan perda yang tidak memenuhi prinsip-prinsip legislasi yang baik (principles of good legislatin), dapat dikembalikan untuk direvisi dan diperbaiki. Meskipun dapat dibayangkan jika proses executive review ini akan memakan waktu yang cukup lama, tetapi hal tersebut tidak akan berarti apa-apa jika dibandingkan dengan kualitas perda yang akan akan dihasilkan nanti. setidaknya dengan menempuh proses executive review secara preventif ini dengan baik, maka upaya judicial review ke Mahkamah Agung akan lebih mampu dikurangi.

\section{Daftar Pustaka}

\section{Buku-Buku}

Asshiddiqie, Jimly, Hukum Tata Negara \& Pilar-Pilar Demokrasi, Sinar Grafika, Jakarta, 2011.

Huda, Ni'Matul, Hukum Tata Negara Indonesia, PT Raja Grafindo Persada, Jakarta, 2010.

Hady, Nuruddin, Teori Konstitusi \& Negara Demokrasi, Setara Press, Malang, 2016.

Mahfud MD, Moh, Membangun Politik Hukum, Menegakkan Konstitusi, PT Raja Grafindo Persada, Jakarta, 2011.

Mahfud MD, Moh, Dasar \& Struktur Ketatanegaraan Indonesia, PT Rineka Cipta, Jakarta, 2001.

M. Hadjon, Philipus, Perlindungan Hukum Bagi Rakyat di Indonesia, Peradaban, 2007.

Lubis, M.Solly, Hukum Tata Negara, CV. Mandar Maju, Bandung, 2008.

\section{Daftar Peraturan Perundang-undangan}

Undang-Undang Dasar Negara Republik Indonesia Tahun 1945
Undang-Undang Republik Indonesia Nomor 2 Tahun 2018 tentang Majelis Permusyawaratan Rakyat, Dewan Perwakilan Rakyat, Dewan Perwakilan Daerah, dan Dewan Perwakilan Rakyat Daerah

Undang-Undang Nomor 23 Tahun 2014 tentang Pemerintahan Daerah sebagaimana telah diubah beberapa kali dan terakhir dengan Undang-Undang (Lembaran Negara Republik Indonesia Tahun 2014 Nomor 244, Tambahan Lembaran Negara Republik Indonesia Nomor 5587)

Undang-Undang Nomor 9 Tahun 2015 tentang Perubahan Kedua Atas UndangUndang Nomor 23 Tahun 2014 tentang Pemerintahan Daerah. (Lembaran Negara. Republik Indonesia Tahun 2015 Nomor 24)

Undang-Undang Nomor 12 Tahun 2011 tentang Pembentukan Peraturan PerundangUndangan (Lembaran Negara Republik Indonesia Tahun 2011 Nomor 82, Tambahan Lembaran Negara Republik Indonesia Nomor 5234) 